EESTI NSV TEADUSTE AKADEEMIA TOIMETISED. 23. KOIDE KEEMIA * GEOLOOGIA. 1974, NR. 2

ИЗВЕСТИЯ АКАДЕМИИ НАУК ЭСТОНСКОН ССР. ТОМ 23 ХИМИЯ * ГЕОЛОГИЯ. 1974, № 2

удК $551.332 .212: 551.332 .54(474.2)$ A.-M. РЫУУК

\title{
О ТЕКСТУРАХ МОРЕН В ДРУМЛИНАХ СРЕДНЕЙ ЭСТОНИИ
}

Морены, слагающие целиком или покрывающие плащом различной мощности друмлины Эстонии (Doss, 1906; Hausen, 1913; Barkla, 1935; Orviku, 1957; Орвику, 1961; Каяк, 1965; и др.), литологически весьма разнообразны. Немалый интерес представляет изучение текстур этих моренных толщ, которые, несмотря на трудности интерпретации, позволяют судить об условиях формирования друмлинового рельефа. Однако литература по геологическому строению и генезису друмлинов не изобилует подробными сведениями об этом вопросе. Нанболее детально текстурные особенности морен, участвующих в строении друмлинов и подобных им форм рельефа, освещены в работах Г. Ферчильда (Fairchild, 1907, 1929), Дж. Слейтера (Slater, 1929), К. Вирккала (Virkkala, 1952), Г. Райта (Wright, 1957), Э. Ивенсона (Evenson, 1971), А. Хилла (Hill, 1971), Г. Юханссона (Johansson, 1972). K сожалению, исследователи Прибалтики мало уделяли внимания названной выше проблеме. Отмечалось лишь, что ориентировка галек в моренах друмлиновых полей совпадает с ориентировкой друмлинов или отличается от нее незначительно (Raukas, 1961; Раукас, 1962, 1972а; Страуме, 1968; и др.). Кроме того, по устному сообщению Я. Страуме и В. Юшкевича, в Буртниекском друмлиновом поле (Северная Латвия) имеются морены, обладающие псевдослоистой текстурой:

В настоящей статье излагаются данные, накопленные за двухлетний период изучения (1971-1972 гг.) Саадъярвского друмлинового поля. Вместе с дополнительными сведениями, собранными в окрестностях городов Пайде (Тюриское друмлиновое поле) и Пыльтсамаа, они позволили несколько уточнить представление о текстурах поверхностных моренных горизонтов ряда друмлинов Средней Эстонии.

Текстуры морен в изученных друмлинах напоминают текстуры в друмлиновых полях других регионов (Fairchild, 1929; Slater, 1929; Virkkala, 1952; Johansson, 1972; и др.) и различных других типов гляцигенного рельефа (Dreimanis, Reaveley, 1953; Virkkala, 1961; Гайгалас, 1971, 1972; Раукас и др., 1971; Раукас, 1973; Лаврушин, 1969, 1970а, б; и др.). Проявляются они в наличии слоистости, псевдослоистости и сланцеватости, господствующей ориентировки и закономерного наклона удлиненных обломков. Псевдослоистость морен вызвана присутствием тонких глинистых или песчаных слойков и жилок, сосредоточением галек и валунов на определенных субгоризонтальных или параллельных склону уровнях, а также переслаиванием разноокрашенных моренных слоев и прослоек. Реже встречаются следы захвата пород ложа и внедрения морены в нижележащие песчано-гравистые отложения. 
Перечисленные текстурные признаки, многие из которых устанавливаются только после детального изучения хорошо очищенных и просохших крупных обнажений, бывают самого разнообразного происхождения. При этом первичные текстуры, возникшие непосредственно во время моренообразования, в некоторых случаях трудно отличимы от вторичных текстур, появившихся в процессе постседиментационного изменения отложений под действием выветривания, периодического промачивания и просыхания, а также других факторов.

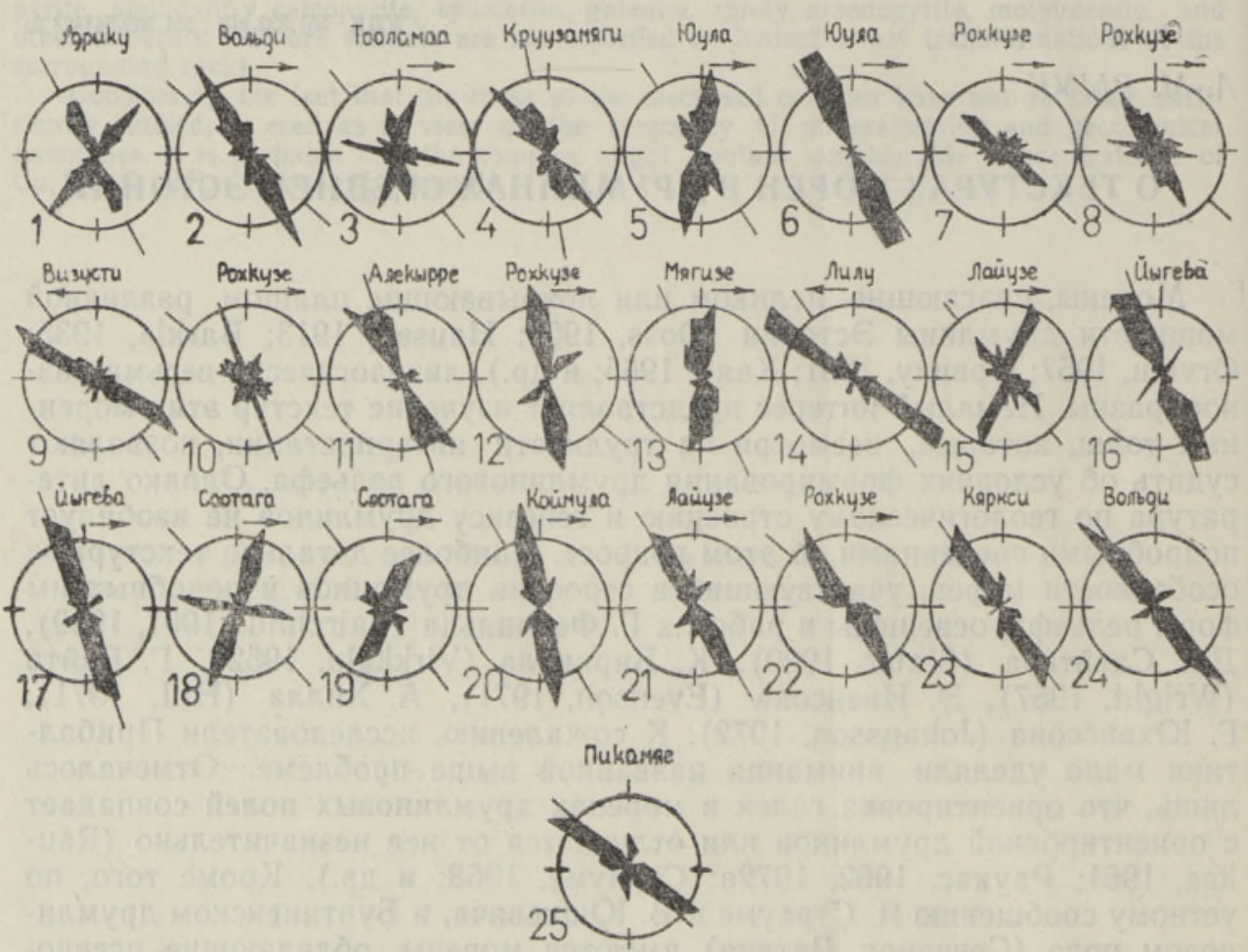

Рис. 1. Примеры ориентировки галек в моренах друмлинов и друмлиноподобных гряд в Саадъярвском друмлиновом поле. Круговая линня соответствует $10 \%$; прямая линия показывает простирание гряды. Если замеры произведены на северо-восточном склоне, стрелка над розой-диаграммой указывает направо, а если на юго-западном склоне налево. Остальные диаграммы характеризуют ориентировку галек в привершинной части гряд.

Б. Крыговский (1966) по характеру слоистости выделяет хорошо слоистые, неяснослоистые и лишенные слоистости морены. Из них в моренах друмлиновых полей Средней Эстонии, во всяком случае в их поверхностной части, имеют наибольшее распространение лишенные слоистости (монолитный или массивный тип текстуры) суглинистые и супесчаные разновидности морен, в которых только узколокально обнаруживается неясная горизонтальная сланцеватость. Высокая уплотненность, отражением которой является устойчивость вертикальных обнажений, и хорошая ориентировка галек (рис. 1, диаграммы 2, 5, 6, 9, 12, 13, 14 и др.), расположенных приблизительно горизонтально, наряду с такими показателями, как относительно большое количество глинистых частиц и отсутствие ясных следов водной переработки, явно свидетельствуют о субгляциальном отложении массивных моренных суглинков. Они выпа- 
дали уже из активного ледника, возможно, в зоне замедленного пластичного течения льда, как полагает Ю. Лаврушин (1970б).

Прежде чем перейти к описанию псевдослоистости морен, следует особо остановиться на их сланцеватости, поскольку она напоминает своеобразную микростратификацию и служит как бы соединяющим звеном между монолитными и псевдослоистыми моренами, хотя последние могут быть и рассланцованы. Наиболее отчетливо сланцеватость проявляется в суглинистых и глинистых моренах, способных поддаваться значительному уплотнению (Flint, 1948; и др.).

Ввиду того что причины возникновения и критерии разграничения сланцеватостей разного типа и псевдосланцеватости недостаточно разработаны, не совсем ясно, действовали ли факторы, опособствующие появлению сланцеватости, уже во время послойного откладывания моренного материала из активного ледника, либо она является постседиментационным признаком, связанным с подледным диагенетическим уплотнением осадка. Возможность возникновения горизонтальной сланцеватости на этапах диа-и эпигенеза морен хорошо иллюстрируется наблюдениями А. Раукаса (1972б) над такими же текстурами в плотных лимногляциальных глинах нижне- и среднеплейстоценового возраста. Тем не менее она, по всей вероятности, вызвана не только статической нагрузкой, но и, в первую очередь, динамическим воздействием движущегося льда, как отмечает Е. Шанцер (1966). В частности, на это указывает упорядоченная ориентировка длинных осей галек и валунов, совпадающая с плоскостями отдельностей рассланцованной морены. Именно такое совпадение отражает первичный, гляциодинамический характер сланцеватости (Гайгалас, 1971).

Плоскости раздела в сланцеватой морене часто имеют тонкую песчаную присыпку. Это явление - не результат послойного вытаивания на поверхность ледника и частичной водной переработки морены, поскольку она плотна и удлиненные обломки в ней ориентированы в направлении движения ледника, а скорее всего доказательство в пользу процессов режеляции, активно протекающих в мореносодержащем льду. Соответствуюшие текстуры описаны Ю. Лаврушиным $(1969,1970$ а, б).

Уместно отметить, что как обычную сланцеватость, так и сланцеватость в сочетании с псевдоморфозами по шлирам режеляционного льда лучше всего связывать с пластичным течением льда по внутренним плоскостям скольжения и воздействием активного льда на отложенную морену. Несколько иную природу имеет нечеткая вертикальная сланцеватость, встречающаяся в радиальноморенной гряде * Круузамяги в восточной части Саадъярвского друмлинового поля. Вертикальная сланцеватость обычно возникает при двусгороннем боковом давлении (Gaigalas, 1969; Гайгалас, 1968, 1971). Описанная гряда сформировалась, видимо, в зоне сочленения двух ледниковых потоков, имевших разные направления и скорости движения. Вертикальную сланцеватость в данном случае нельзя объяснить выдавливанием водонасыщенной морены в подледниковые трещины (экструзией) (Virkkala, 1961; Hoppe, 1952; и др.), так как гальки расположены в морене горизонтально и они ориентированы вдоль проскирания гряды (рис. 1, диаграмма 4), а не поперек нее. О слиянии ледниковых потоков свидетельствует также залегание маломощного слоя красно-бурой малокарбонатной морены, принесенной из впадины Чудского озера потоком льда юго-западного направления, на типичной желтовато-серой карбонатной морене (рис. 2) со следами ледникового напора.

* Радиальные морены - переходные формы между озами и друмлинами (Раукас и др., 1971). 

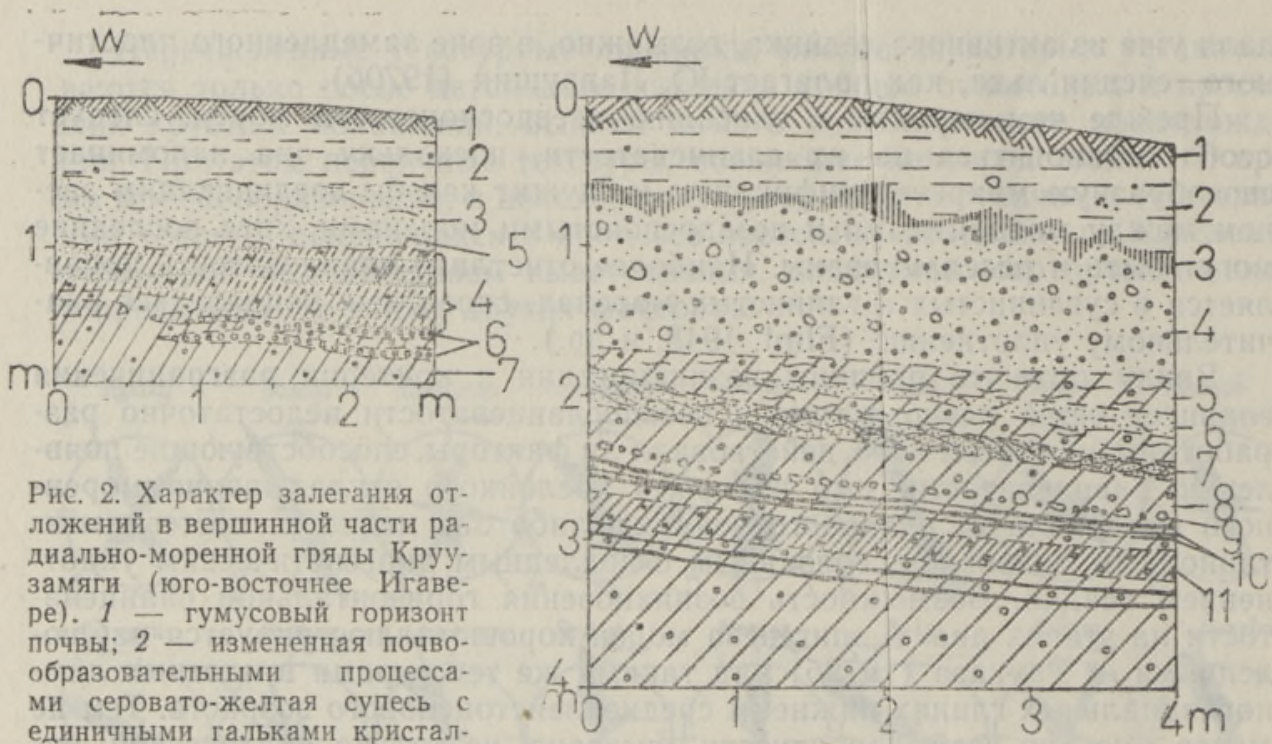

Рис. 2. Характер залегания отложений в вершинной части ра диально-моренной гряды Круузамяги (юго-восточнее Игавере). 1 - гумусовый горизонт почвы; 2 - измененная почвообразовательными процессами серовато-желтая супесь с единнчными гальками кристаллических пород; 3 - волнистослоистый мелкий песок; 4 красно-бурая рыхлая супесча ная морена; 5 - мелкие выкли нивающиеся линзочки и жилки песка в красно-бурой морене; 6 - мелкий гравий; 7 - желтовато-серая плотная суглинистая морена.

\section{Гляциодинамическая} сланщеватость, во многих случаях скрытая или слабозаметная, часто выявляется постседиментаци онными процессами (Гайгалас, 1968, 1971). Если гляциодинамическая сланцеватость слабозаметна, ее легко перепутать с вто-

Рис. 3. Разрез отложендй на северном склоне поперечной долины в проксимальной части друмлина Юула (западнее оз. Элиствере). 1 - гумусовый горизонт почвы; 2 - ювмененная почвообразовательными процессами серовато-желтая неслоистая, местами пористая пылеватая супесь; встречаются единичные гальки кристаллических пород; 3 - прослойка светло-коричневого тяжелого суглинка с неясными переходами, возникшего в процессе почвообразования; 4 - слабо отсортированный галечни ковый гравий с примесыю супесчаного материала (абляционная морена?); 5 - мелковолнисто-сланцеватая серовато-желтая суглинистая морена; 6- неслоистый песчаный мелкий гравий; 7 - косослоистый песчаный мелкий гравий; 8 - мелкосланцеватая желтовато-серая плотная супесчано-суглинистая морена; 9 - галечниковая «мостовая» в толще желтовато-серой морены; 10 - глинистые прослойки и жилки серого и темно-коричневого цвета в толще желтовато-серой морены; 11 - сланцеватая темно-коричневая платная суглинистая морена.

ричными отдельностями десквамации. Последние возникают на старых склонах и откосах (Шанцер, 1966). Вторична и мелковолнистая сланцеватость в проксимальной части друмлина Юула (рис. 3), обусловленная сползанием морены вниз по уклону в перигляциальных условиях позднеледниковья.

Интересны гляциодинамические текстуры в друмлинах Восточной Финляндии, подробно описанные К. Вирккала (Virkkala, 1952), аналоги которых встречены и в других областях материкового оледенения (Slater, 1929; Ramsden, Westgate, 1971; Knutsson, 1971; и др.). Это глинистые темные прослойки, которые отдельными тонкими лентами или сериями слойков (рис. 4) простираются иногда на десятки метров. К. Вирккала (Virkkala, 1952) объясняет формирование этих слоиков скачкообразным перемещением вверх подошвы движущегося льда, поскольку придонные слои ледника, перегруженные обломочным материалом, относительно пассивны. Если согласно К. Вирккала описанные текстуры отражают плоскости сдвига, то по Ю. Лаврушину (1969) такая слоистость свидетельствует о послойно-пластичном течении льда вдоль поверхностей 


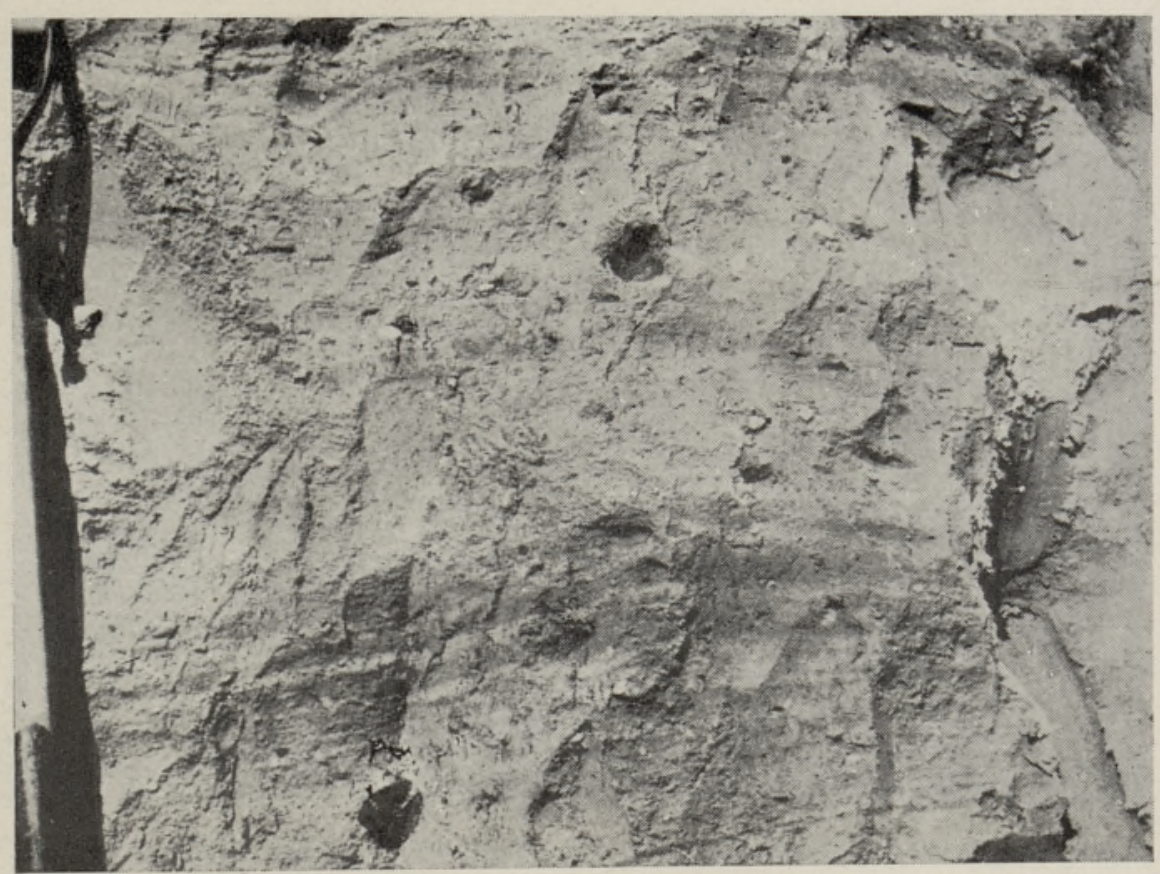

Рис. 4. Темные глинистые ленты в плотной суглинистой основной морене на восточном склоне друмлина Соомевере (Саадъярвское друмлиновое поле). Фото автора.

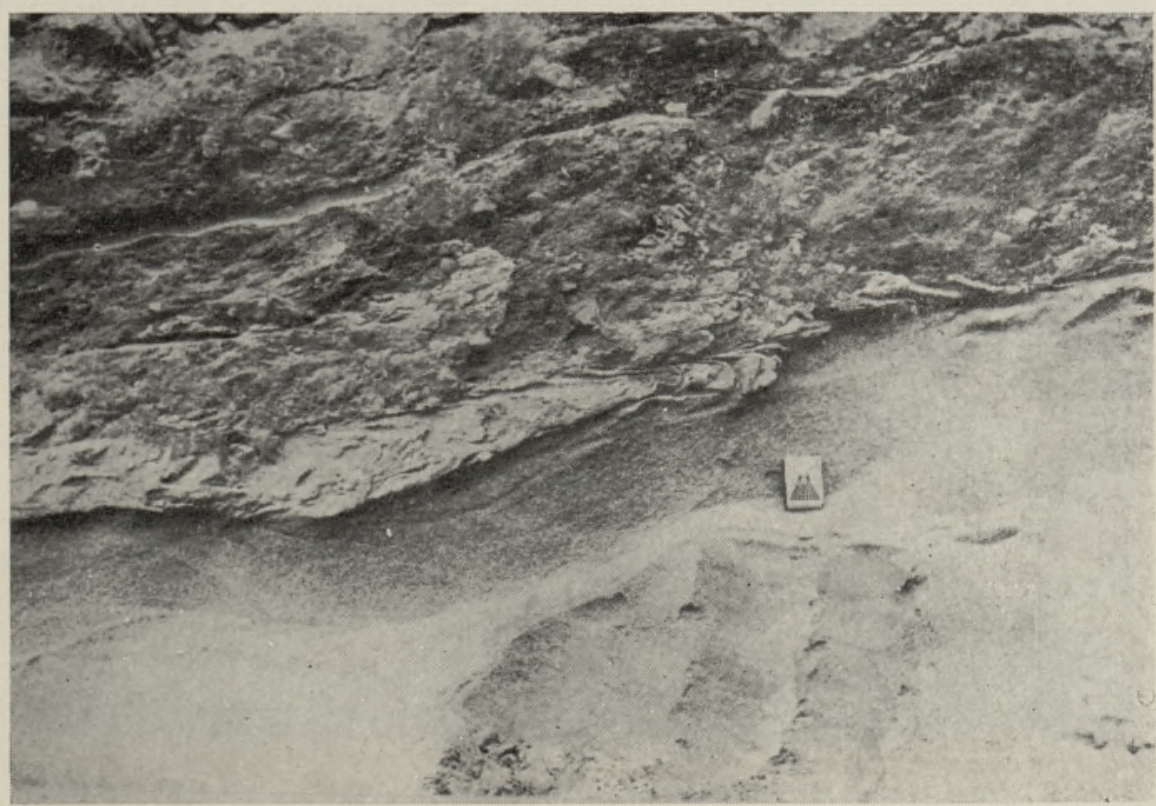

Рис. 5. Текстуры захвата в друмлине Рохкузе (Саадъярвское друмлиновое поле). Направление движения льда справа налево. Фото автора. 


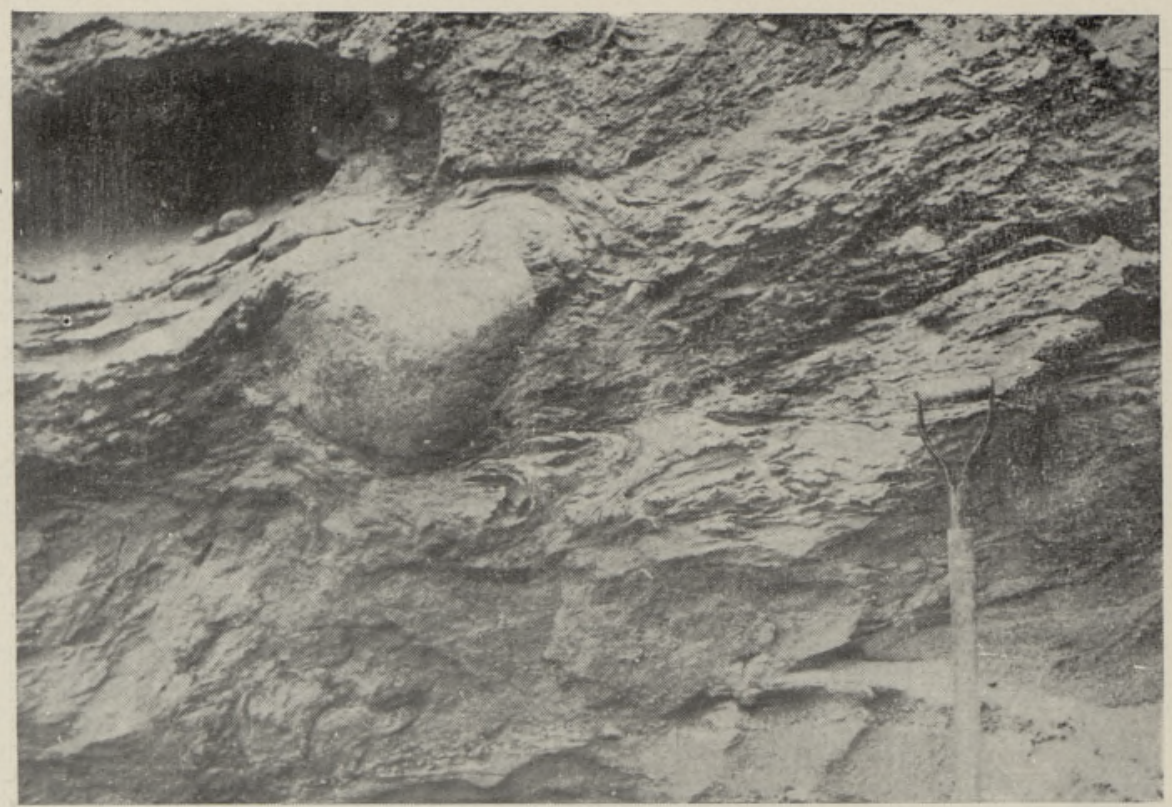

Рис. 6. Рассланцованнал псевдослоистая морена в друмлине Рохкузе, показывающая текстуру течения выдавливания (?) связанную с наличием упора в виде валуна, и микроскладки. Фото автора.

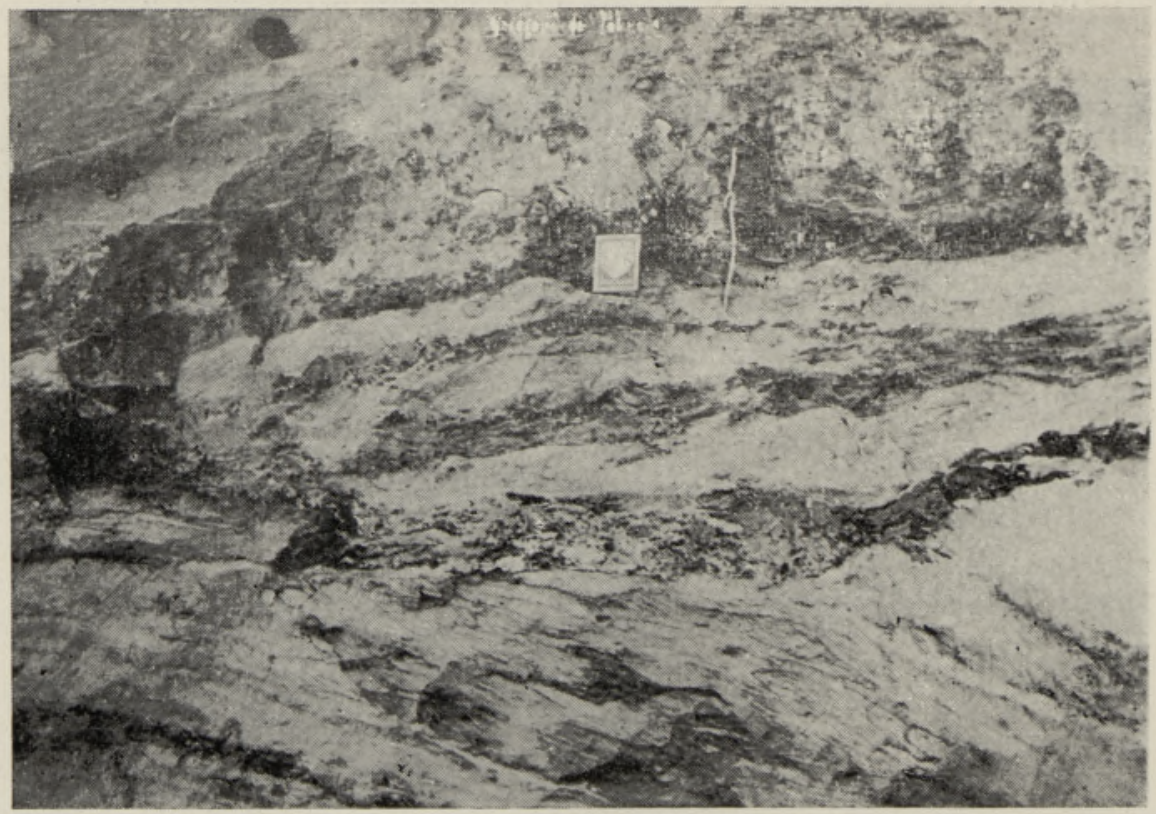

Рис. 7. Субаквально отложенная рыхлая красно-бурая морена, переслаивающаяся с водно-ледниковыми песками и алевритами. Круузамяги. Фото автора. 
внутреннего скольжения. Не исключено, что таким же движением льда и его частичным вытаиванием обусловлены тонкие суглинистые оболочки темного цвета вокруг многих валунов, от которых кое-где отходят горизонтальные микроязыки (рис. $8, \overline{5}$ ). Последние напоминают описанные выше глинистые ленты. Чаше всего такая оболочка с «ответвлениями» окружает только задний торец валуна.

В случае сосредоточения галек и валунов на определенных уровнях, обычно беспорядочно расположенных в толще основной морены, появляются своеобразные прослойки различной плотности (рис. 8). Некоторые авторы (Dreimanis, Reaveley, 1953; и др.) называют их валунными «мостовыми». Әти галечно-валунные прослойки переходят в горизонтальном направлении через пунктирную слоистость, описанную Е. Рухиной (1960), в обычную текстуру с рассеянным расположением крупных обломков (так наз. «raisin-cake structure» (Virkkala, 1952, 1961; и др.)). Такое послойное скопление галек и валунов могло образоваться в процессе удаления мелких частиц и оставления на месте более крупных обломков под напором быстрее скользящих моренных слоев (Dreimanis, Reaveley, 1953), особенно в период временной ледниковой эрозии уже отложенной морены (Holmes, 1941), а также в результате неодинакового распределения галек и валунов в теле ледника.

В результате неравномерного разноса подстилающих пород возникли гляциодинамические текстуры захвата. При этом масса подстилающих пород как бы втягивается в нижние горизонты морены в виде наклоненных в сторону движения ледника языков (рис. 5), которые переходят в горизонтальные полосы, постепенно распадающиеся на отдельные разорванные гнезда и линзы. Вместе с текстурами захвата иной раз встречаются нерегулярной формы внедрения морены в нижележащие отложения (рис. 8), которые Н.-А. Мернером (Mörner, 1972) вслед за A. Дрейманисом (Dreimanis, 1969) принимаются за специфический вид моренных клиньев, образуюшихся при надвигании ледника на талые отложения ложа.

Спорной остается природа текстур, обнажающихся на восточном склоне друмлина Рохкузе. В первом приближении псевдослоистость, облекающая кристаллический валун, может служить примером текстур течения выдавливания (рис. 6), ранее описанных Ю. Лаврушиным (1969 и др.). Похожая текстура могла возникнуть также в процессе вытаивания льда, при котором отложения, непосредственно примыкающие к валуну, проседали меньше, чем на некотором от него удалении.

В проксимальной части Юулаского друмлина морена имеет редкую текстуру, напоминающую слоистость зандровых и других водно-ледниковых отложений (рис. 9). Ей свойственно пестрое сочетание линзочек и жилок разнородного материала наподобие текстур, наблюдаемых в современных ледниках (Лаврушин, 1970б; Boulton, 1971). Не исключено, что она появляется в зоне интенсивного дробления льда вблизи выступа подледникового рельефа (в данном случае склона друмлина), где имелись резкие перепады скоростей движения и повышенные горизонтальные давления (Лаврушин, 1970б). Однако к применению метода актуализма при изучении текстур моренных отложений следует все же относиться с большой осторожностью.

Характерна также неясная горизонтальная слоистость (возможно, псевдослоистость) в виде чередования полос морены (мощностью $1-2$ м), имеющих несколько различающийся гранулометрический состав. Такая расплывчатая полосчатость может быть вызвана неонинаковой нагрузкой обломочного материала в леднике или изменением характера седиментации. 


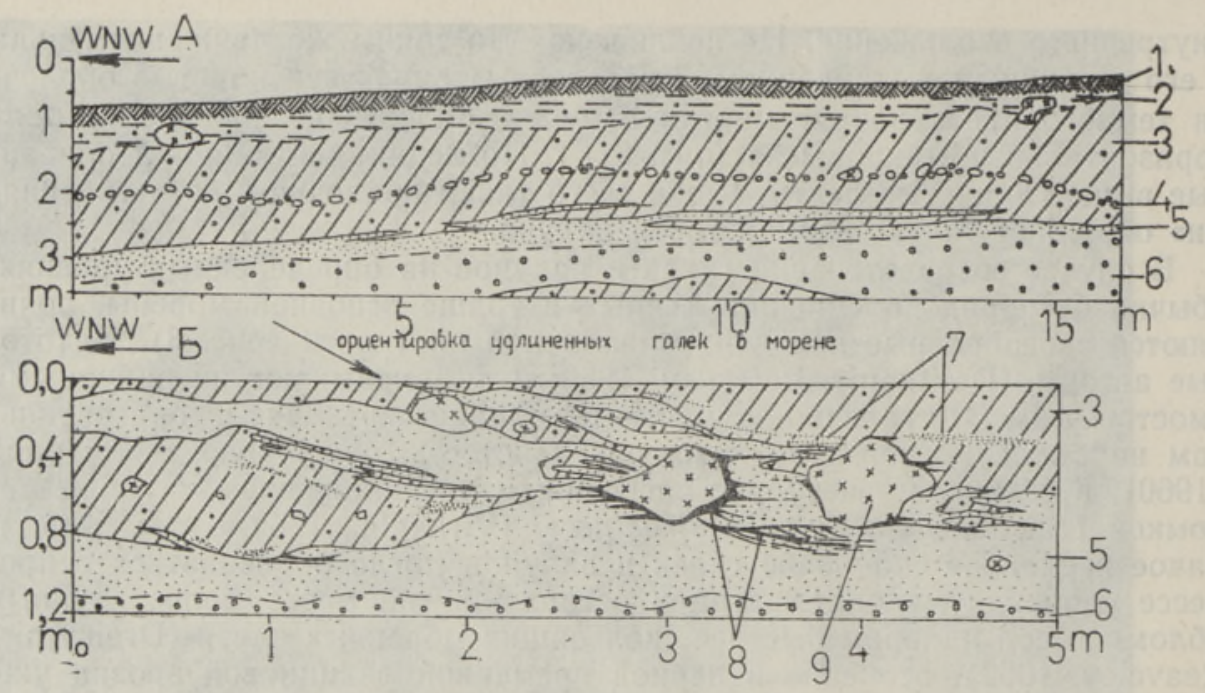

Рис. 8. Схематический разрез прнповерхностных отложений у западного подножия пологого друмлина в Паламузе (A) и деталь зоны контакта между флювиогляциальными отложениями и покрывающей мореной (Б) в 10 ю юго-западнее разреза $A$.

1 - гумусовый горизонт почвы; 2 - серовато-желтая неслоистая супесь с отдельными гравийными зернами и валунами кристаллических пород; 3 - мелкосланцеватая желтовато-серая плотная суглинистая морена, в самых низах с выклинивающимися линзочками и прослойками песка; 4 - галечниковая «мостовая» в толще морены; 5 - неслоистый средний песок; 6 - песчанистый гравий; 7 мелкие линзочки и прослойки песка в морене; 8 - темно-серый безвалунный суглинок; 9 - кристаллические валуны.

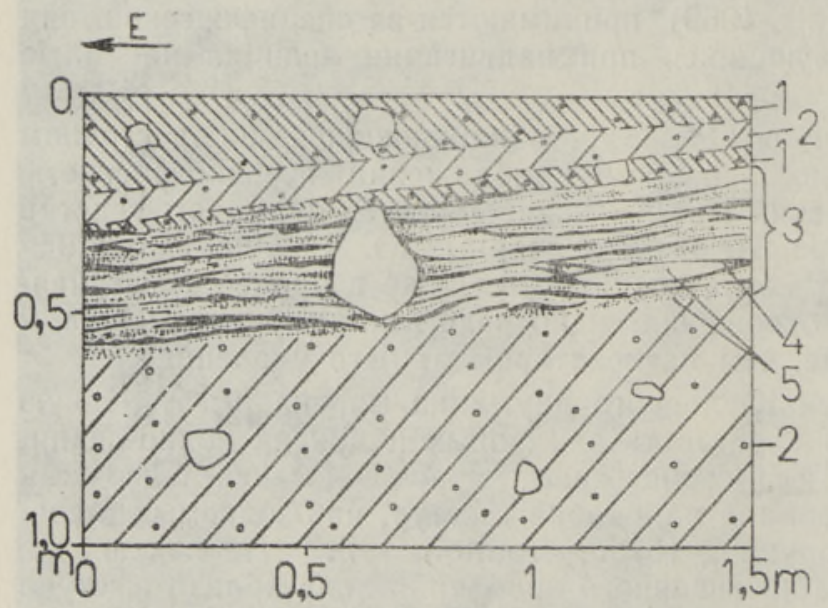

Рис. 9. Разрез отложений на южном склоне поперечной долины в проксимальной части друмлина Юула. 1 - сланцеватая плотная коричневая суглинистая морена; 2 - сланцеватая желтовато-серая плотная морена супесчаного и суглинистого состава; 3 - сероватожелтая супесчано-суглинистая плотная морена; 4 - серые и темно-серые суглинистые прослойки и жилки в серовато-желтой морене; 5 - выклинивающиеся линзочки и жилки мелкого пес-

ка в серовато-желтой морене.

Заканчивая рассмотрение гляциодинамических текстур, отметим, что они имеют в пространстве постепенные переходы, отражающие такие же переходы в динамическом состоянии базальных слоев ледника.

Слоистость морен в друмлинах иногда вызвана отложением обломочного материала в водной среде. Слоистые морены водного происхождения (рис. 7) относительно рыхлы, гальки в них расположены довольно часто вертикально или не имеют четкой ориентировки в одном направлении, и вся порода носит отчетливые следы водной переработки в виде многочисленных прослоек песка и супеси. А. Раукасом (1973) описана субаквально отложенная слоистая морена, переходящая в водно-ледни- 
ковые отложения, в Реаствере (северная часть Саадъярвского друмлинового поля).

Интересна рыхлая горизонтально-слойстая морена со следами водной переработки, покрывающая на восточном подножии Соотагаского друмлина (Саадъярвское друмлиновое поле) водно-ледниковые пески и алевриты. Гальки в ней ориентированы вниз по уклону (рис. 1, диаграммы $18,19)$, что вместе с другими текстурными признаками (рыхлость, невыдержанные прослойки песка и т. д.) позволяет считать эту морену аналогом наплывной морены («flow-till») Бултона (Boulton, 1971).

Из всех элементов текстуры морен, участвующих в строении друмлинов, наиболее детально изучена ориентировка длинных осей галек. В свете исследований последних лет, основанных на большом количестве замеров, распространено мнение о том, что ориентировка галек в моренах друмлиновых полей совпадает с простиранием друмлинов (Норре, 1951; Virkkala, 1951; Wright, 1957; Raukas, 1961; Раукас, 1962, 1972a, 1973; Страуме, 1968; и др.). Это мнение, однако, нуждается в уточнении соответственно конкретным геолого-геоморфологическим условиям. Выяснено, например, что ориентировка галек в приповерхностных моренных горизонтах может существенно отличаться от простирания друмлинов, а значит и от предполагаемого направления движения ледников (Andrews, King, 1968; Embleton, King, 1969; и др.). Изменяется ориентировка галек также с глубиной (Gravenor, Meneley, 1958; Embleton, King, 1969; Hill, 1971; и др.) и по разным элементам (склонам, вершинам и т. д.) друмлинных гряд** (Harris, 1971; Johansson, 1972; и др.). Многочисленные анализы, произведенные автором на друмлинах Средней Эстонии, согласуются с последними данными.

Наилучшее совпадение ориентировки галек и простирания друмлинов наблюдается в относительно низких и узких грядах (рис. 1, диаграммы $16,17,23,24)$, которые не обладают типичным асимметричным продольным профилем. Но пока трудно судить, является ли это общим правилом или нет. Не выяснено также, как изменяется ориентировка галек при движении из приповерхностных слоев в более глубокие горизонты. Случайные замеры, произведенные на близких уровнях, не выявили никакой закономерности. В друмлине Юула, например, ориентировка галек на глубине 2,1 $м$ примерно совпадает с простиранием друмлина, а на глубине 3,4 м отличается от него на $40^{\circ}$ (рис. 1 , диаграммы 5 и 6 ). В проксимальной части друмлина Нава ориентировка галек на бо́льших глубинах в одном случае совпадает с направленнем гряды лучше, чем у поверхности (рис. 10, диаграмма 1), в другом - хуже (рис. 10, диаграмма 3). Не исключено, что такие расхождения случайны.

Весьма характерно, что ориентировка галек в привершинной части друмлинов совпадает с простиранием гряд лучше, чем на боковых склонах и у подножия. При этом наблюдается схождение преобладающего направления длинных осей галек, находящихся на противоположных боковых склонах, в сторону дистальной и осевой частей друмлинов (рис. 10). Отклонение от направления продольной оси друмлинов, которое на склонах одной и той же гряды бывает неодинакового значения, может превышать $30^{\circ}$, но обычно колеблется в пределах $10-20^{\circ}$. Если боковые склоны друмлинов имеют неодинаковые углы наклона, то наибольшее расхождение ориентировки галек отмечается на более крутых

** Қак известно, в моренах друмлинов гальки обычно хорошо ориентированы в одном направлении. Поэтому нами в каждой точке по горному компасу определялись азимуты только 50 удлиненных галек. При этом учитывалось, что большое количество рассеянных в пространстве анализов отражает направление движения ледника лучше, чем малое количество очень детальных замеров (Dreimanis, Reaveley, 1953). Tакое же заключение вытекает из исследования Л. Kауранне (Kauranne, 1960). 

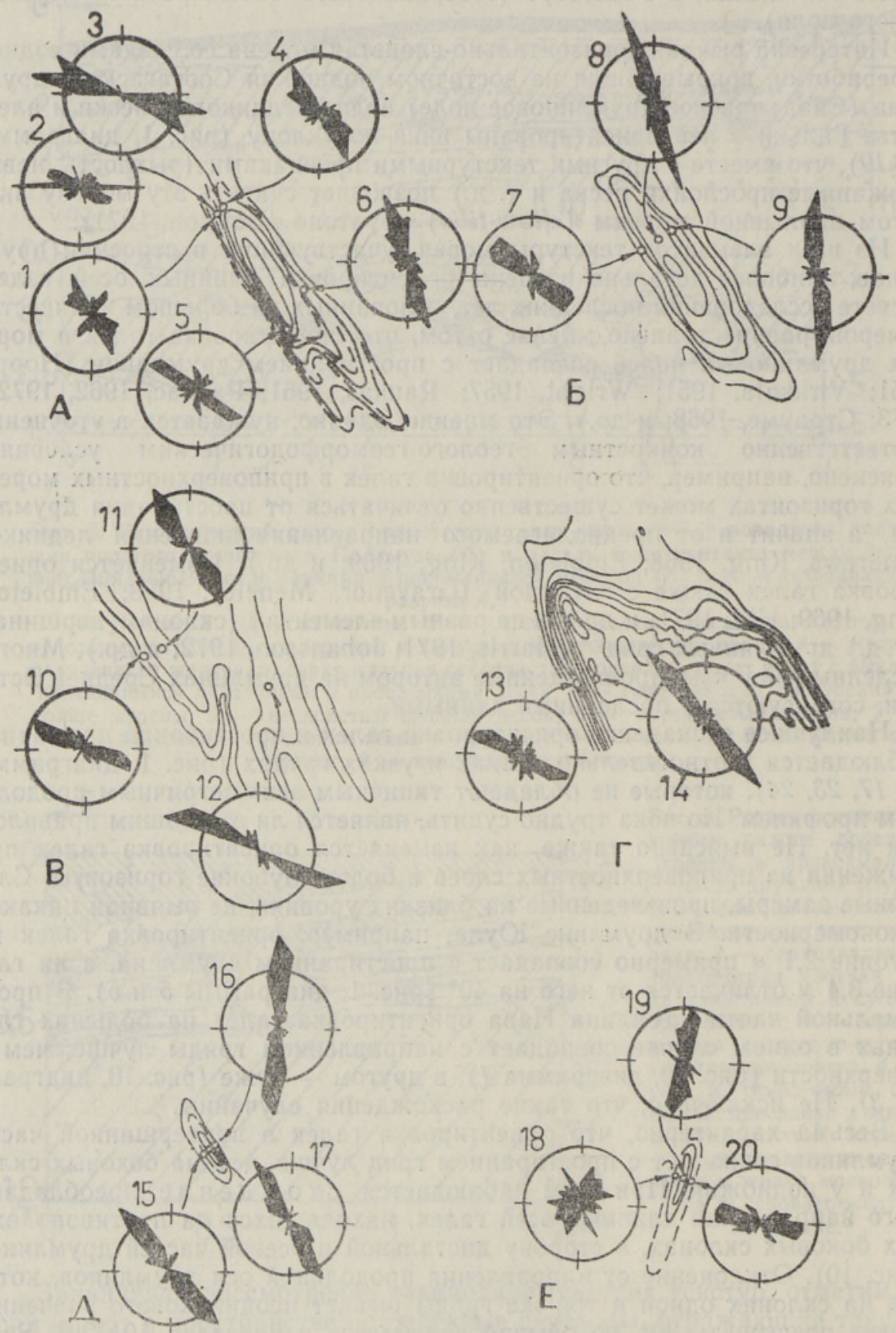

Рнс. 10. Ориентировка галек в моренах на разных элементах друмлинов. $A$ - друмлин Нава, 5 - друмлин Лаане, $B$ - окрестности Паламузе, $\Gamma$ проксимальная часть друмлинового плато Раадувере (Саадъярвское друмлиновое поле), Д - Пиллимяги (восточнее г. Пыльтсамаа), $E$ - друмлин Реопалу (западнее г. Пайде). Все замеры произведены на глубинах 1,5-2 $\boldsymbol{м}$, за исключением № 1 (2,7 $м$ ) и № $3(3,5$ м) в Наваском друмлине. 
склонах, которые, как правило, направлены в сторону наиболее глубоких междрумлиновых депрессий.

В случае нарушения первичной ориентировки галек оползнеподобными и солифлюкционными процессами, они, вероятно, приобрели бы другое расположение - более или менее перпендикулярное к склону друмлина, как в наплывной морене Соотагаского друмлина или на склонах Реопалуского друмлина (рис. $10, E$ ), который длительное время находился в субаквальных условиях. Кроме того, гальки даже на крутых (более $10^{\circ}$ ) склонах расположены горизонтально или наклонены в сторону, противоположную движению льда, только в исключительных случаях больше $5^{\circ}$. Учитывая и другие текстурные особенности морен, описанное несоответствие ориентировки галек и друмлинов можно объяснить только гляциодинамическими причинами.

Г. Юханссон (Johansson, 1972), описавший геологическое строение и генезис друмлиноподобных гряд Вестерботтена в Швеции, во многих случаях имеющих скальное ядро, объясняет небольшое расхождение между основной ориентировкой галек и направлением гряд (в некоторых случаях наблюдается и конвергенция галек в дистальную сторону) неровностями скального субстрата, вызвавшими нарушения в направлении движения потока льда во время отложения морены. Судя по геологическому строению друмлинов Саадъярвского поля, не имеющих ск ального ядра из твердых пород, и учитывая значительные относительные высоты этих друмлинов, более правдоподобным кажется, что описанное схождение галек обусловлено неодинаковой статической и динамической нагрузкой ледника на друмлины и междрумлиновые понижения. Такое предположение, высказанное при объяснении генезиса валообразных гряд Альберты в Канаде (Gravenor, Meneley, 1958), недавно нашло поддержку и дальнейшее обоснование со стороны Э. Ивенсона (Evenson, 1971). Согласно этой гипотезе, моренный материал медленно перемещается из зон высокого давления (междрумлиновых понижений) в зоны пониженного давления (в сторону друмлинов). Из-за уменьшения градиентов давления в сторону осевой линии друмлинов гальки приобретают на этой линии ориентировку, которая соответствует общему направлению движения льда.

Рис. 11. Идеализированная схема о закономерностя ориентировки галек в некоторых друмлинах Средней Эстонии и соотношения предполагаемых путей двнжения моренного материала и общего направления движения льда в заключительные фазы друмлинизации.

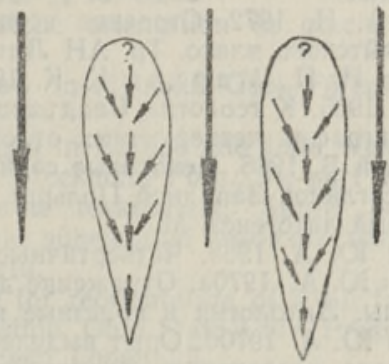

Нет основания полагать, что в процессе формирования и эволюции друмлинов разной морфологии и разного геологического строения морфогенетические процессы оставались бы неизменными. Возможно, что динамическая экструзия моренного материала приобрела большое значение только в заключительные фазы формирования друмлинов определенной морфологии и определенного внутреннего строения. Предварительные результаты изучения ориентировки галек в наиболее представительных друмлинах Средней Әстонии, говорят, во всяком случае, в пользу такого процесса, хотя по данным М. Уолкера (Walker, 1971, цитируется по Harris, 1971) во многих друмлинах Канады наблюдается ориентиров- 
ка галек, как бы облекающая контуры друмлина, что не согласуется с нашими данными.

Таким образом, ориентировка галек в изученных друмлинах часто не результат и отражение одного лишь поступательного движения ледника, а итог сочетания движения ледника и миграции обломочного материала из зон высокого давления в зоны пониженного давления (рис. 11). Этим же объясняется, почему именно на склонах, граничащих с глубокими впадинами ледникового выпахивания, ориентировка галек больше всего расходится от направления друмлинов - эти склоны подвергались как бы тангенциальному давлению. В связи с этим уместно отметить, что уже в конце 30-х годов И. Герасимов и К. Марков (1939) одни из первых высказали мысль, что друмлины частично формировались в результате выдавливания.

Из изложенного выше можно сделать заключение, что откладывание моренного материала при друмлинизации происходило частично уже под активным ледником, как справедливо отмечено К. Орвику (Orviku, 1957; Орвику, 1961) и многими другими авторами. При этом в некоторых случаях определенную роль играла динамическая экструзия обломочного материала в результате чередования зон повышенного и пониженного подледникового давления. Друмлинообразование является своеобразным ледниковым процессом, активно протекающим в специфических гляциодинамических условиях при сочетании неравномерной, но одновременной ледниковой аккумуляцин моренного материала и эрозии подстилающей поверхности.

За просмотрение рукописи и ценные советы автор выражает благодарность К. Орвику, А. Раукасу, А. Мийделю, а также всем коллегам, участвовавшим при сборе матернала для данной работы.

\section{ЛИТЕРАТУРА}

Гайгалас А. И. 1968. Сланцеватость плейстоценовых морен Литвы. Мат-лы науч. конфер. молодых ученых геологов Литвы. Вильнюс.

Гайгалас А. 1971. Структура, текстура и генетические разновидности основных морен. В сб.: Строение и морфогенез Средне-Литовской моренной равнины Вильнюс.

Г айг ал а с А. И. 1972. Строение неоллейстоценового моренного покрова ВосточноЖямяйтского плато. Тр. АН ЛитССР, сер. Б, 2 (69), 3 (70), 4 (71).

Гер асимов И. П., М ар ков К. К. 1939. Четвертичная геология. М.

К а я К К. Ф., 1965. К геологии Саадъярвского друмлинового поля. В сб.: Литология и стратиграфия четвертичных отложений Эстонии. Таллин.

К ры го в ски й Б. 1966. Некоторые седнментологические параметры и свойства моренных суглинок Западной Польши. В сб.: Современный и четвертичный континентальный литогенез. М.

Л а в р ушин Ю. А. 1969. Четвертичные отложения Шіпицбергена. М.

Л а в р уш и н Ю. А. 1970а. Отражение динамики движения ледника в строении донной морены. Литология и полезные ископаемые, 1.

Л а в р ушин Ю. А. 1970б. Опыт выделения фаций и субфаций в донной морене материкового оледенения. Литология и полезные ископаемые, 6.

О р в и ку К. К. 1961. Геологическое строение друмлинов Эстонии. Мат-лы Всес. совещ. по изуч. четвертичн. периода, т. 2. М.

Р а ука с А. 1962. Закономерности распределения галек в моренах Әстонии. Изв. АН ЭССР, Сер. физ.-матем. и техн. наук, XI, № 2.

P а ук а с А. В. 1972а. Значение анализа руководящих валунов и ориентировки длинных осей галек в моренах при изучении динамики ледниковых покровов (на материалах Прибалтики). Мат-лы гляциологических исследований. Хроника. Обсуждения, вып. 19. М.

Р а ук а с А. В. 19726. Формирование плейстоценовых отложений и гляцигенных форм рельефа Эстонии. Автореф. докторской диссертации. Таллин.

Р а ук а с А. 1973. О генезисе морен Эстонии. Изв. АН ЭССР, Хим. Геол., 22, № 1.

$\mathrm{P}$ а ук а с А., Р я хн и Э., М и й де л А. 1971. Краевые ледниковые образования Северной Әстонии. Таллин. 
Р у х и н а Е. В. 1960. Литология моренных отложений. Л.

Стр ау ме Я. Я. 1968. Морфология и строение друмлинов юro-западной Латвии. Мат-лы V конфер. геологов Прибалтики и Белоруссии. Вильнюс.

Ш а нце р Е. В. 1966. Очерки учения о генетических типах континентальных осадочных образований. М.

A ndrews J. T., King C. A. M. 1968. Comparative till fabrics and till fabric variability in a till sheet and a drumlin: a small-scale study. Yorkshire Geol. Proc., 36, 4.

B a rkl a H. 1935. The drumlins of Türi (Estonia). Tartu Olik. j.o. Loodusuurijate Seltsi aruanded, 42.

B ou 1 t o n G. S. 1971. Till genesis and fabric in Svalbard, Spitsbergen. In: Till/A Symposium. Ohio State Univ. Press.

Doss B. 1906. Gutachten über das Projekt einer Grundwasserversorgung der Stadt Dorpat. Riga.

Dreimanis A. 1969. Till wedges as indicators of direction of glacial movement. Abstracts with program, Geol. Soc. Amer. Annual Meeting. Atlantic City.

Dreimanis A., Reaveley G. H. 1953. Differentiation of the lower and the upper till along the north shore of Lake Erie. J. Sediment. Petrology, 23, 4.

Emblet on C., King C. A. M. 1969. Glacial and periglacial geomorphology. Edinburgh.

Even s o E. B. 1971. The relationship of macro- and microfabric of till and the genesis of glacial landforms in Jefferson County, Wisconsin. In: Till/A Symposium. Ohio State Univ. Press.

Fairchild H. L. 1907. Drumlins of Central Western New York. New York State Mus. Bulletin, 111.

Fairchild H. L. 1929. New York drumlins. Proc. Rochester Acad. Sci., 7.

Flint R. F. 1948. Glacial geology and the Pleistocene epoch. New York.

$\mathrm{Gaigalas} \mathrm{A.} \mathrm{1969.} \mathrm{On} \mathrm{structure} \mathrm{and} \mathrm{genesis} \mathrm{of} \mathrm{ground} \mathrm{moraines} \mathrm{of} \mathrm{Neopleistocene} \mathrm{in}$ Lithuania. Zeszyty Naukowe Univ. im. Adama Mickiewicza w Poznaniu, Geografia, 8.

Gravenor C. P., Meneley W. A. 1958. Glacial flutings in central and northern Alberta. Amer. J. Sci., 256, 10.

$\mathrm{H}$ a r r is S. A. 1971. The nature and use of till fabrics. In: Research methods in Pleistocene geomorphology. Proceedings: 2nd Guelph Symposium on Geomorphology, 1971. Guelph, Ontario.

H a u se n H. 1913. Ober die Entwicklung der Oberflächenformen in den russischen Ostseeländern und angrenzenden Gouvernements in der Quartärzeit. Fennia, 34, 3.

$\mathrm{H}$ i11 A. R. 1971. The internal composition and structurè of drumlins in North Down and South Antrim, northern Ireland. Geogr. Annaler, 53, h. 1.

Holme s C. D. 1941. Till fabric. Geol. Soc. Amer. Bulletin, 52, 9.

H op p e G. 1951. Drumlins i nordöstra Norrbotten. Geogr. Annaler, 33, h. 3-4.

Hop pe G. 1952. Hummocky moraine regions, with special reference to the interior of Norrbotten. Geogr. Annaler, 34, h. 1-2.

Joh ansson H. G. 1972. Moraine ridges and till stratigraphy in Västerbotten, North Sweden. Sveriges geol. Unders., ser. C, 673. Arsb. 66, 4.

Ka uranne L. K. 1960. A statistical study of stone orientation in glacial till. Bull. Comm. géol. Finlande, 188.

Knuts s o G. 1971. Studies of ground-water flow in till soils. Geol. Fören. Stockholm Förh., 93, part 3, 546.

Mörner N.-A. 1972. The first report on till wedges in Europe and Late Weichselian ice flows over southern Sweden. Geol. Fören. Stockholm Förh., 94, part 4, 551.

Orviku K. 1957. Eesti NSV-s esinevate voorete tekkimisest. Suure Sotsialistliku Oktoobrirevolutsiooni 40 -ndale aastapäevale pühendatud teaduslik sessioon. Ettekannete teesid. (Tartu Riiklik Olikool). Tartu.

R a msden J., Westgate J. A. 1971. Evidence for reorientation of a till fabric in the Edmonton area, Alberta. In: Till/A Symposium. Ohio State Univ. Press.

$\mathrm{R}$ a u k a S A. 1961. Mandrijää liikumisest Eestis. Eesti Loodus, 5.

S laterG. 1929. The structure of the drumlins exposed on the south shore of Lake Ontario. New York State Mus. Bulletin, 281.

Virkka la K. 1951. Glacial geology of the Suomussalmi area, East Finland. Bull. Comm. géol. Finlande, 155.

V i rkk a l a K. 1952. On bed structure of till in eastern Finland. Bull. Comm. géol. Finlande, XXV, 157.

Virkkala K. 1961. On the glacial geology of the Hämeenlinna region, southern Finland. Bull. Comm. géol. Finlande, XXXIII, 196.

W r ig h t H. E. Jr. 1957. Stone orientation in Wadena drumlin field, Minnesota. Geogr. Annaler, 39, h.1. 


\section{MOREENIDE TEKSTUURIDEST KESK-EESTI VOORTES}

Kesk-Eesti kōige paremini väljakujunenud voorestikes täheldatavad moreenide tekstuuri iseärasused tổendavad, et need moreenid on suuremalt osalt välja settinud juba aktiivse liustikujää all. Veeriste orientatsiooni iseäralikku lahkuminekut voorte suunast on võimalik seletada moreeniosakeste aeglase kandumisega suurema dünaamilise ja staatilise survega liustikualastest vöönditest (voortevahelistest vagumustest) voorte kohal paiknenud văiksema survega vöönditesse.

\section{A.-M. ROUK}

\section{ON THE TILL STRUCTURES IN THE DRUMLINS OF CENTRAL ESTONIA}

The author presents some preliminary data about the great variability in the structure of the upper till sequences in the drumlins of Central Estonia, mainly in the Saadjärve drumlin field. Although many drumlins here exhibit no obvious structure (massive type of till), some tills rich in clay and silt display fissures and distinct glaciodynamic structures. Among the glaciodynamic structures, boulder pavements (Figs. 3 and 8), stratified till (Fig. 4) similar to structures described by K. Virkkala (1952), entrapment structures (Fig. 5), extrusion (?) structures with microfolds (Fig. 6), involutions of till into stratified drift (Fig. 8) and complex structures of unclear origin (Fig. 9) occur. The presence of glaciodynamic structures, high density of till and good orientation of elongated pebbles in tills (Fig. 1) enable to assume that a considerable part of the upper till sequences in the drumlins described have been accumulated under active glaciers of the last glaciation. However, in some places water-laid stratified till (Fig. 7) and loose flowtill with innumerable lenses and microlayers of silt and fine sand likewise occur.

The elongated pebbles in the topmost part of the drumlins are mostly parallel to the ridges, but fabrics from the slopes of many drumlins show a trend to rise up-slope towards the lee part of the drumlins (Fig. 10). It is supposed by the author that such an effect may have been caused by the subglacial transport of the drift particles from zones of higher static and dynamic pressure towards the low pressure zones near the tops of the drumlins. The effect of this process (dynamical extrusion) upon the fabrics is shown in the idealized scheme (Fig. 11). These data are in good agreement with the ideas of C. P. Gravenor and W. A. Meneley (1958) and E. B. Evenson (1971). We suppose that the dynamic extrusion of the till might have taken place during the final phases of the formation of certain drumlins, only. 